\title{
Education in Eastern Europe and Eurasia.
}

By NADIA INVANENKO. (Bloomsbury Series on Education Around the World) pp. 360. New York and London: Bloomsbury. 2014. f100.00. Hardback. ISBN: 9781623564803.

'The only way to reach the level of contemporary Western countries is through education', claimed Ataturk, identifying education as central to the establishment of the current Republic of Turkey, or indeed any country. Quoted by O. Bolat in his chapter on educational leadership in Turkey, this idea repeatedly surfaces throughout Education in Eastern Europe and Eurasia. This book is part of a series, dedicated to exploring the history and current development of education systems in different parts of the world. This volume deals with Belarus, Moldova, Russia, Ukraine, Armenia, Azerbaijan and Georgia, affording the majority of this book a post-soviet analysis. Turkey and Israel are also included in this volume and acknowledged as anomalous countries in the region.

Following the collapse of the Soviet Union, former soviet republics have undergone fundamental and far-reaching reforms within a narrow timeframe. The education system and curriculum in the soviet period was heavily based on communist ideology. In the aftermath of 1989, such a system was no longer compatible with the direction towards democratic governance and new market economies. As a result, education emerged as a key priority during the transitional period. The focus of this volume is an examination of how each country in this region has handled educational transitions in order to conform to the new, pressing needs of the $21^{\text {st }}$ century. Each contributor analyses how these transitions have affected: literacy; social mobility; and public satisfaction with the education sector.

The form of the volume makes it extremely accessible. Each chapter investigates a particular country and is written by a separate author. The collaboration involved in its production is palpable and impressive. Chapters begin with an exposition of the socio-political issues affecting a region, so that each country can be seen in the light of its distinct history. Moldova has struggled to create solid political institutions following centuries-long occupation in the presoviet period and constant alterations of its borders, leaving the country with little experience of managing its affairs independently. Other countries, like Ukraine and Armenia, have faced difficulties balancing the modernisation of education with the need to revive cultural and linguistic identity. Outside of the post-soviet filter, Israel has grappled with constructing a system that accommodates its hugely diverse population.

The lack of high-quality teachers is an issue reiterated in many chapters. Most experts have identified low salaries as the principal reason for this, which has led to a decline in the social status of the profession. Consequently, less and less graduates enter the profession and many in it choose to migrate. Few countries appear to be making a conscious effort to reverse this tendency. Russia has committed to significantly raising and maintaining teachers' salaries. Azerbaijan has granted teachers a more active role in shaping and advising the government. On the other hand, Turkey's well-intentioned reforms to increase and motivate professional development have backfired and lead to further alienation between teachers and the Ministry of National Education.

More optimistically, the post-soviet countries have made significant progress in creating and determining education systems that were initially unfamiliar. Overhauling an entire ideology and the society that grew up within it posed a monumental challenge, but each region has succeeded, to varying degrees, in 
constructing a system that is at least satisfactory. As expected, the larger and more economically prosperous countries have greater levels of school enrolment and students within the higher education system than smaller states, which are often dependent on aid and lacking in resources. Nevertheless, they must be seen through the small state filter to contextualise their progress relatively.

Returning to Ataturk, what is clear from this volume is the extent to which education is fundamental to the reconstruction of a state. Whether experiencing the communist epicentre crumble, desperately seeking EU membership, or adapting to a constantly-changing state of affairs, these countries have sought to create education systems that reflect Western values and imitate Western paradigms. Western models and investment in education have consolidated its economic and social prosperity. By attempting to follow Western models, the contributors to this volume seem unanimous in their optimistic tone for the future of education in Eastern Europe and Eurasia.

One thing this book takes for granted, however, is whether the Western education system should indeed be emulated. Anyone living in the West is surely familiar with the intense, domestic criticism their education systems face, ranging from basic failures in literacy to producing generations of culturally unaware students. This idealised, elevated image of the Western system as an exemplar for Eastern Europe does appear inadequate. Perhaps a study of the discrepancies between the idealisation of the Western education system in Eastern Europe and its scandalous status in the West would make an interesting focus for the volume on Western Europe.

LISA NICHOLSON

School of Slavonic and East European Studies

University College London

This work is licensed under the Creative Commons Attribution-NonCommercial-ShareAlike 4.0

International License. This license lets others remix, tweak, and build upon work noncommercially, as long as they credit the author and license their new creations under the identical terms. To view a copy of this license, visit http:/ / creativecommons.org/licenses/by-nc-sa/4.0/. 